\title{
As religiões diante da preocupação última da vida: uma reflexão a partir do pensamento de Paul Tillich
}

\author{
Claudio de Oliveira Ribeiro* \\ André Yuri Gomes Abijaudi**
}

\section{Resumo}

A pesquisa apresenta os resultados da discussão em torno do conceito de religião entendido pelo teólogo Paul Tillich e como ele se liga ao que o autor denominou preocupação última e à importância dela para a vida humana. Metodologicamente, foram dados passos na direção de uma sistematização do conceito tillichiano de preocupação última, e de uma análise de como ele pode ser relacionado à proposta do diálogo entre as religiões, com a indicação de temas religiosos mobilizadores como a salvação. Além disso, para esta discussão recorremos também à possibilidade de um diálogo da teologia de Tillich com a teologia latino-americana. Entre os resultados da pesquisa, destacamos aspectos da vivência religiosa nos quais a preocupação última não é somente mais uma função do espírito humano, mas a que concede sentido e profundidade a todas as funções criativas da vida humana e que aponta para o caminho da autotranscendência. Há também de se considerar a situação social opressiva e os problemas cruciais da sociedade e da vida humana que necessitam ocupar a reflexão teológica, especialmente a soteriológica, levando em conta as ambiguidades da vida humana, o desejo por salvação e as possibilidades de uma teologia das religiões.

Palavras-chave: Religião. Preocupação última. Ambiguidades. Salvação. Teologia das religiões.

* Doutor em Teologia pela PUC-RJ. Professor Titular de Teologia e Ciências da Religião da Universidade Metodista de São Paulo. Currículo Lattes: <http://buscatextual.cnpq.br/ buscatextual/visualizacv.do?id=K4703975P3>

** Bacharel em Teologia pela Universidade Metodista de São Paulo. Mestre em Ciência da Religião pela Universidade Federal de Juiz de Fora. Currículo Lattes: < http://buscatextual. cnpq.br/ buscatextual/visualizacv.do?id=K4315748Y3> 


\section{Religions in front of the ultimate concern of life: a reflection from the thought of Paul Tillich}

\section{Abstract \\ This research presents the results of the discussion around the concept of religion understood by the theologian Paul Tillich and how it relates to what the author called ultimate concern and the importance of it for human life. Methodologically, directions were taken towards a systematization of tillichian's concept of ultimate concern, and an analysis of how it can be related to the proposed dialogue between religions, indicating mobilizers religious themes as salvation. In addition, for this discussion also appealed to the possibility of a dialogue between Tillich's and Latin American's theologies. Among the search results, we highlight aspects of religious experience in which the ultimate concern is not only more a function of the human spirit, but the one that gives meaning and depth to all creative functions of human life and that points to the path of self-transcendence. There is also to consider the oppressive social situation and the crucial problems of society and human life that need to occupy the theological reflec- tion, especially the soteriological taking into account the ambiguities of human life, the desire for salvation and the possibility of a theology of religions.- \\ Key-words: Religion. Ultimate concern. Ambiguities. Salvation. Theology of religions. \\ Las religions en la preocupación última de la vida: un reflejo del pensamiento de Paul Tillich}

\section{Resumen}

La investigación presenta los resultados de la discusión sobre el concepto de la religión entendida por el teólogo Paul Tillich y cómo se relaciona con lo que el autor llama la preocupación última y la importancia de la misma para la vida humana. Metodológicamente, se dieron pasos hacia una sistematización del concepto tillichiano de la preocupación última, y un análisis de la forma en que puede estar relacionado con el diálogo propuesto entre las religiones, lo que indica movilizadores temas religiosos como la salvación. Además, para esta discusión también un llamamiento a la posibilidad de un diálogo de la teología de Tillich con la teología latinoamericana. Entre los resultados de la búsqueda, destacamos los aspectos de la experiencia religiosa en que la preocupación última no sólo es más una función del espíritu humano, pero que da sentido y profundidad a todas las funciones creadoras de la vida humana y que apunta al camino de la auto-trascendencia. También hay que considerar la situación social opresivo y los problemas cruciales de la sociedad y la vida humana que deben ocupar la reflexión teológica, especialmente el soteriológica, teniendo en cuenta las ambigüedades de la vida humana, el deseo de salvación y la posibilidad de una teología de las religiones.-

Palabras clave: Religión. Preocupación última. Ambigüedades. Salvación. Theología de las religiones. 
As religiōes diante da preocupação última da vida: 351

uma reflexão a partir do pensamento de Paul Tillich

\section{Introdução}

Estabelecer um conceito ou definir um significado para religião é sempre uma tarefa árdua para os estudiosos do campo das ciências da religião. Há culturas, sobretudo orientais, que não concebem a religião de forma conceitual. Soma-se a isso o fato que as análises acerca dos rumos da religião e a discussão sobre a configuração teórica e prática desse campo no contexto brasileiro, devido à complexidade dele, tornam o desafio cada vez maior para o pensamento acadêmico. Assim, nossa pesquisa possui um recorte e estamos conscientes das limitações dele. Esta exposição se apropria da compreensão da religião a partir do pensamento de Paul Tillich, um dos mais destacados teólogos europeus do século XX. Muitos teólogos de sua época entendiam a religião a partir de sua etimologia e, muitas vezes, se apropriavam da premissa exclusivista da teologia cristã tradicional para reafirmar a ideia de que somente a fé cristã pode "religar o ser humano a Deus". Outros teólogos cristãos se arriscavam um pouco mais e valorizavam as demais confissões religiosas; contudo reafirmavam que o cristianismo não seria apenas mais uma religião, mas sim uma revelação final e absoluta da verdade divina. Tillich rejeita ambas as ideias. Sua compreensão a respeito da religião, parte daquilo que ele denominou de Ultimate Concern - traduzido neste artigo como preocupação última - e que revela a latente necessidade humana de encontrar um sentido e um significado incondicional para a vida.

Essa compreensão de Tillich abre espaço para que possamos observar a vida e a dimensão religiosa de formas mais amplas. Na compreensão de Tillich, a vida humana se encontra em um contexto de ambiguidades, na mistura dos elementos essenciais e existenciais. A religião também não escapa dessa realidade, mas possui suas próprias ambiguidades. Também, o tema do pluralismo religioso e do diálogo entre as religiões vem ganhando espaço no debate acadêmico atual. No Brasil, especialmente, a temática religiosa está quase sempre também entrelaçada com o debate da laicidade do Estado.

Diante desses aspectos, o objetivo deste artigo é refletir sobre esse conceito que Tillich apresenta e discutir como as religiões - entendendo-as aqui em suas constituições mais genéricas - se comportam se observadas a partir da perspectiva da preocupação última. Para Tillich, a preocupação última não é somente mais uma função do espírito humano. Ela é o que concede sentido e profundidade a todas as funções criativas da vida humana e que aponta para o caminho da autotranscendência. Evidentemente, em função da amplitude do debate, não seria possível abarcar todas as discussões que envolvem o 
diálogo inter-religioso, muito menos as especificidades de cada religião. De toda forma, esperamos que, sob a ótica da teologia e da compreensão de Tillich, possamos contribuir e repensar a discussão das temáticas da fé e do diálogo entre as religiões, observando faces ambíguas da vida humana.

As temáticas relativas à salvação e como tais visões estão relacionadas ao que estamos discutindo sobre a preocupação última do ser humano mobilizam intensamente os debates teológicos e pastorais, não somente na América Latina, mas no mundo todo. Assim como outros aspectos da teologia sistemática, o tema tem sofrido fortes questionamentos de diferentes procedências e intenções. Um dos mais destacados polos de crítica surge dos ambientes que têm privilegiado o diálogo inter-religioso. Nossa pressuposição é que as reflexões de Tillich, especialmente o debate sobre a preocupação última, podem ser relevantes para o tema.

Paul Tillich ofereceu, com sua teologia da cultura, um testemunho da natureza não totalitária do cristianismo. Nesse sentido, sua teologia encontra-se em sintonia com a contribuição, no contexto católico-romano, de Karl Rahner e do Concílio Vaticano II para a teologia das religiões. Tillich fez a crítica ao absolutismo eclesiocêntrico da Igreja Católica Romana e à perspectiva exclusivista de Karl Barth, no contexto teológico protestante. Não obstante, questionou o modelo inclusivista, ao indicar a necessidade de se ressaltar o caráter absoluto do cristianismo como uma religião histórica. As bases teológicas do seu pensamento são pertinentes para se pensar um modelo pluralista de interpretação das religiões.

\section{A religião como preocupação última e sua relação com o conceito de fé}

"O encontro pessoal com Deus e a reunião com ele constituem o cerne de toda religião autêntica” (TILLICH, 2014, p. 378). Essa afirmação foi feita por Paul Tillich, no segundo volume de sua obra denominada Teologia Sistemática, quando discorria sobre o fracasso dos esforços humanos na busca e projeção de uma autossalvação. ${ }^{1}$ Essa afirmação de Tillich aponta para uma compreensão que pressupõe um sentimento humano na busca de

Tillich considera fundamental que se faça uma crítica à história da religião na medida em que ela é a história das tentativas e fracassos experimentados pelo ser humano em seu empenho de salvar a si mesmo. Para ele, a religião é o âmbito em que se formula a tentativa da ruptura entre o ser essencial e o ser existencial. Nesse ponto, Tillich aponta que essa possibilidade só pode ser alcançada pela presença e atuação do Novo Ser, identificado no cristianismo com a pessoa de Jesus, o Cristo (Cf. TILLICH, 2014, p. 372-381). 
um poder transformador que possa responder a todas as suas preocupações preliminares e ao angustiante problema da finitude. A religião entendida por Tillich parte do conceito de "preocupação última", um dos mais utilizados no pensamento do autor para se referir às questões do âmbito religioso.

Em termos de definição, Tillich entende a preocupaşão última como a tradução abstrata do mandamento encontrado na Bíblia cristã, ancorado no Evangelho de Marcos 12,29: "O Senhor, nosso Deus, é o único Senhor. Amarás, pois, o Senhor teu Deus de todo o teu coração, de toda a tua alma, de todo o teu entendimento e de toda a tua força" (TILLICH, 2014, p. 29). Esse pressuposto afirmativo não faz de Tillich um teólogo de posicionamento exclusivista e muito menos um fundamentalista cristão. $\mathrm{O}$ enunciado simplesmente quer afirmar que a preocupação religiosa é última. Ela desapossa todas as outras preocupações de uma significação última, transforma-as em preliminares e secundárias. Para Tillich, a preocupação última é incondicional e independente de qualquer condição de caráter, desejo ou circunstância. A preocupação incondicional é total, e por esse motivo é também infinita. Assim se firma a preocupação religiosa: última, incondicional, total e infinita.

A palavra "preocupação", para Tillich, aponta para o caráter "existencial” da experiência religiosa. Ele considera que embora a religião pertença às funções da vida espiritual do ser humano e seja, portanto, uma expressão da vida em geral, unindo os elementos essenciais com elementos existenciais - ou seja, da vida com ambiguidades - somente deve-se fazer referência a ela em termos da existência. Para Tillich, a religião não escapa das ambiguidades da vida. Ela é ambígua como toda a vida e está, assim, constituída dos elementos essenciais e existenciais. Não se deve confundir religião com revelação, pois é dessa forma que a religião se torna distorcida e se encontra com a problemática da autossalvação, fracassando naquilo que tenta conseguir. Contudo, como mencionado, Tillich considera que é no ambiente da religião que a vida sem ambiguidade pode ser recebida, essencialmente a partir da figura do Novo Ser e da presença e atuação do poder do Espírito divino. Também, não se pode falar adequadamente do "objeto da religião" sem remover seu caráter de objeto. Para ele, a religião não é apenas mais uma função da vida ao lado das outras, mas também é no contexto da religião que a vida recebe aquele que vence as ambiguidades da vida: para ele, o Espírito divino (TILLICH, 2014, p. 372).

Além disso, aquilo que é "último", para Tillich, só se dá a si mesmo na atitude de preocupação última. É o correlato de uma preocupação incondi- 
cional, mas não se trata de "alguma coisa superior" chamada "o absoluto" ou "o incondicionado", a respeito do qual se pudesse argumentar com fria objetividade. Tillich considera que o último é o objeto de uma entrega total, exigindo também, enquanto se olha para ele, a entrega da subjetividade humana. Por isso, nesse sentido, a preocupação última, não necessariamente precisa se identificar com Deus, mas sim com aquilo que pode se tornar deus para o ser humano. Trata-se de uma questão de paixão e interesses infinitos, ${ }^{2}$ transformando o ser humano em objeto toda vez que ele tenta transformar em objeto essa preocupação última. Por esse motivo, Tillich evita termos como "o último", "o incondicional", "o universal", "o infinito" etc. e fala da preocupação que é última, incondicional, total e infinita (TILLICH, 2014, p. 29). Essa preocupação última é o que leva o indivíduo a arriscar a sua própria vida, e o leva a considerar algo na vida pelo qual se deve dar a própria vida. Por isso a preocupação última é, para Tillich, uma questão existencial, ou seja, uma questão do ser.

Nesse sentido, deve-se também considerar a íntima relação que o conceito de religião tem com o conceito de fé em Tillich. Para ele, fé é um dos conceitos que primeiro precisam "ser curados", antes de poderem curar. Em outras palavras, para ele o conceito de fé é um dos mais incompreendidos, distorcidos e mal definidos da linguagem religiosa, seja ela erudita ou popular (TILLICH, 1985, p. 5). Estritamente, para Tillich, fé é estar possuído por aquilo que toca o ser humano de forma incondicional. A fé conduz o ser humano para além das preocupações preliminares e o coloca em dedicação total àquilo que ele identifica como sua preocupação suprema, ou a chamada preocupação última.

É importante ressaltar que Tillich considera que mesmo as preocupações que não sejam urgentes, isto é, que não sejam imprescindíveis para a vida de um indivíduo ou comunidade, podem se transformar em preocupação última de acordo com a importância e o sentido que elas recebem. Quando isso acontece, a preocupação em foco exige dedicação total por parte daquele que aceita a sua exigência e lhe promete realização perfeita. Esse é o caso quando, por exemplo, um povo faz da vida e do crescimento da nação sua

\footnotetext{
2 O termo "paixão infinita" é apropriado por Tillich da filosofia de Kierkegaard que, por sua vez, identifica o conceito de paixão infinita com a fé. Por isso, como leitor de Kierkegaard, Tillich coloca o elemento absoluto da preocupação última do ser humano como algo que exige essa intensidade absoluta, essa paixão infinita que coloca o ser em direção àquilo que é ou se torna em deus para ele.
} 
preocupação última, que lhe exige sacrifício de todas as coisas como bem-estar, saúde, família, justiça e humanidade. Forças extremas de nacionalismo servem como modelo para expressar o que Tillich compreende como idolatria. Nesse caso exemplificado, o deus único do povo é a nação. De toda forma, esse deus acaba demonstrando seu caráter demônico quando explicita a exigência incondicional levantada por uma preocupação última. Entretanto, Tillich diferencia esse tipo de nacionalismo da fé que se manifestou na religião do povo judeu do Antigo Testamento. Para ele, apesar da tentativa do nacionalismo judaico de distorcer o caráter da nação, a preocupação última do povo, no caso citado, é o Deus da justiça, o chamado Deus Todo-Poderoso, o Deus de todo povo, porque para todo ser humano ele encarna a justiça. Essa seria a preocupação incondicional e última de todo judeu devoto e por isso é proclamado o mandamento de maior importância com a expressão "Amarás o Senhor teu Deus de todo o teu coração, de toda a tua alma, e de toda a tua força" (Dt 6.5). Nisto também está expresso o sentido da preocupação última, como estar possuído incondicionalmente, e é desse mandamento supremo que deriva o conceito da preocupação última, ou do que preocupa o ser humano de forma incondicional (Cf. TILLICH, 1985, p. 5-7). Assim, retomando a primeira citação deste artigo, se há encontro pessoal com esse Deus da justiça, para Tillich, há religião autêntica.

A compreensão desse encontro pessoal do ser humano com Deus é fundamental para se estabelecer uma relação entre religião e fé no conceito de Tillich. Não se trata de mero discurso proselitista que tem intuito de conquistar adeptos para a fé cristã - ou mesmo adeptos ao pensamento tillichiano. Para Tillich, o encontro do ser humano com Deus define aquilo que Tillich vai definir como o encontro do ser com o ser-em-si, ou seja, do ser com o fundamento do seu ser. Em sua compreensão, o ser-em-si não tem princípio nem fim, mas é a origem de todas as coisas (TILLICH, 2014, p. 198). Mas não se trata somente de identificar o ser-em-si com a infinitude, mas sim com aquilo que está além da polaridade de finitude e autotranscendência infinita. No sentido do encontro, o ser-em-si se manifesta ao ser finito nesse impulso do infinito por transcender a si mesmo. Assim, o ser-em-si precede a finitude e precede a negação infinita do finito. Deus, como ser-em-si, é o "fundamento da estrutura ontológica do ser sem, no entanto, se submeter a essa mesma estrutura". É também "o poder de ser em tudo e acima de tudo, o poder infinito de ser" (TILLICH, 2014, p. 242). Como ser-em-si, Deus está além da oposição entre o ser essencial e o ser existencial, o que 
faz dele a fonte de toda possibilidade de uma vida sem ambiguidades. Assim, há fé no encontro com o Deus pessoal, mas, além disso, fé é o estado de ser apoderado pela potência do ser-em-si. O ser-em-si, na percepção ontológica não é somente o ser mais poderoso, mas é o poder de Ser (Cf. TILLICH, 2009, p. 63). Dessa forma, a coragem de ser é uma expressão de fé e, por sua vez, fé é a experiência dessa potência. Nesse sentido, podemos observar o que Tillich afirma:

(...) há fé no encontro com o Deus pessoal. Porém ainda mais do que isto está incluído no conceito de fé. Fé é o estado de ser apoderado pela potência do ser-em-si. A coragem de ser é uma expressão de fé e o que a "fé" significa deve ser entendido através da coragem de ser. Definimos coragem como a autoafirmação do ser a despeito do não-ser. A potência desta autoafirmação é a potência do ser que é efetivo em cada ato de coragem. Fé é a experiência desta potência. Mas é uma experiência que tem um caráter paradoxal, o caráter de aceitar a aceitação. O ser-em-si transcende infinitamente todo ser finito; Deus no encontro divino-humano transcende o homem incondicionalmente. A fé transpõe este vão infinito em aceitando o fato de que a despeito dele a potência de ser está presente, de que aquele que está separado é aceito. (...) A fé não é uma opinião, mas um estado. É o estado de ser apoderado pela potência de ser que transcende tudo que é, e da qual tudo que é participa. Aquele que é apoderado por esta potência é capaz de afirmar-se porque sabe que está afirmado pela potência do ser-em-si (TILLICH, 2001, p. 134).

Como se percebe, para Tillich, a fé é a base da coragem de ser. Isso é decisivo para a questão ontológica, já que a ansiedade da dúvida e o dominante sentimento de insignificância colocam o ser de frente com o problema do não-ser, isto é, de inevitavelmente ter que encarar a morte. Mas nesse contexto da presente discussão, mais importante do que essa questão ontológica é a ênfase no encontro do divino com o humano, do ser com o ser-em-si. A partir da afirmação de Tillich, percebe-se que, nesse encontro, Deus transcende o ser humano incondicionalmente. Em outras palavras, é por meio da fé que acontece a reaproximação do ser com o infinito e faz que o separado seja aceito. Tillich parte do princípio teológico de que o ser humano está separado do ser-em-si por causa do problema da queda. Deste modo, é importante ressaltar que ele não reafirma simplesmente um conceito da teologia cristã tradicional, mas ele parte de uma reinterpretação do existencialismo filosófico que, em certos aspectos, influenciou o seu pensamento. Nesse sentido, para Tillich, a queda nada mais é do que a alienação existencial 
na qual se encontra o ser humano. As ambiguidades da vida, a fragmentação do ser nas polaridades do ser essencial e do ser existencial, colocam o ser na condição de finito e, portanto, separado do ser-em-si que é o fundamento infinito do ser. Nesse sentido, o ser humano também se encontra separado do seu próprio ser original (Cf. TILLICH, 2009, p. 85).

Além disso, observa-se que para Tillich, a fé não está na condição de opinião. Fé é o ato mais íntimo e global do espírito humano, e não somente um processo que ocorre numa seção parcial ou numa função especial da vivência humana (TILLICH, 1985, p. 7). Isso permite a conclusão de que a fé não deve ser discutida, argumentada ou mesmo colocada na posição de ter que se provar a partir de outros critérios que não o seu próprio critério. Fé é estar possuído incondicionalmente, e somente o ser que está possuído por essa fé conhece a intimidade da sua dimensão. Como mencionado, a fé é um ato da pessoa toda e por isso participa de toda a dinâmica da vida pessoal. Nesse sentido, a fé também precisa ser observada como experiência religiosa.

Tillich considera ainda que aquilo que nos toca incondicionalmente torna-se Sagrado (TILLICH, 1985, p. 13). Por isso, ele indica que a base religiosa universal é a experiência do Sagrado dentro do finito. O Sagrado, como realidade teológica e espiritual fundamental, surge nas coisas finitas e particulares, nas concretas e nas universais. Ele é a base sacramental de todas as religiões, e por isso a experiência do ser finito com o Sagrado é, na realidade, uma vivência da preocupação última. Contudo, Tillich considera que essa base que sacramenta a preocupação última está sujeita, por sua finitude, à demonização (RIBEIRO, 2010, p. 58). Esse processo demônico é apontado por Tillich quando ocorre, por exemplo, negação da justiça em nome da santidade. Trata-se do elemento ético, daquilo "que deve ser", da obrigação religiosa ao concreto até a última instância e que impede o ser humano de exercer a sua autonomia.

Para Tillich, a experiência do Sagrado com o finito é experiência do divino. $\mathrm{O}$ coração humano busca pelo infinito porque o finito quer repousar no infinito. A finitude traz angústia ao ser humano quando este precisa deparar-se com a realidade da morte. No infinito, ele consegue projetar a sua própria realização. Por sua vez, ele experimenta simultaneamente a distância infinita entre o finito e o infinito, e com isso experimenta também o veredicto negativo sobre todas as suas tentativas de alcançar o infinito. Dentro dessas tentativas, surge o perigo da fé tornar-se idolatria. Na medida em que o Sagrado atua como demoníaco torna-se em objeto da fé idólatra. Esse é 
o perigo da fé quando se depara com a ambiguidade do Sagrado e a possibilidade deste tornar-se demoníaco. Nesse sentido, para Tillich, a preocupação última como aquilo que toca o ser humano incondicionalmente pode tanto curá-lo como destruí-lo (TILLICH, p. 1985, p. 15).

A fé contém certo elemento contingente e exige risco. Ela combina a certeza ontológica com a incerteza a respeito de todas as coisas condicionadas e concretas. Para Tillich, isso não significa que a fé seja a mesma coisa que a crença. $\mathrm{O}$ risco da fé não quer dizer a aceitação de afirmativas a respeito de Deus, do ser humano e do mundo, mas sim no fato de que o elemento incondicional pode tornar-se questão de preocupação última somente se aparecer de forma concreta. Ela pode manifestar-se por meio de símbolos mitológicos e racionalizados, por intermédio de conceitos teológicos, atividades rituais e sacramentais. Pode ainda aparecer em formas de comportamento, nas exigências proféticas e políticas em favor da justiça social quando se tornam preocupações últimas tanto religiosas como seculares (TILLICH, 2009, p. 65-66).

Esse conceito é também aplicável ao indivíduo, na medida em que ele se comporta de forma justa. Todo ato cultural é ato de um eu centrado e se baseia na autointegração moral da pessoa que está inserida dentro de uma comunidade. Na proporção em que essa pessoa é portadora da autocriação cultural da vida, ela se torna também sujeita a todas as tensões e ambiguidades da cultura. De certo modo, isso torna todo ser humano sujeito às ambiguidades da cultura tanto no sentido subjetivo quanto no objetivo (TILLICH, 2014, p. 526-528). A partir desta consideração, pode-se afirmar que a justiça é o alvo de todas as ações culturais que visam à transformação da sociedade.

\section{As ambiguidades da religião frente às realidades da vida humana}

A dialética da autotranscendência no pensamento de Tillich está no fato de que a vida sob a dimensão do espírito só pode concretizar-se em realidades finitas que são transcendidas. Nesse fato consiste o conceito de que algo que é transcendido é, ao mesmo tempo, não transcendido. Essa é a situação de todas as religiões ao longo da História como ritos, doutrinas e sistema de símbolos. A religião que leva à autotranscendência não é a religião organizada, mas sim a religião como preocupação última. Com essa realidade, torna-se possível observar as ambiguidades da religião a partir de suas realidades essenciais e existenciais. 
Primeiro, é preciso reafirmar que ambiguidade para Tillich trata-se exatamente disso. Ele compreende as ambiguidades da vida como a mistura dos elementos existenciais e essenciais. Em todos os processos da vida estão mesclados os elementos essenciais e existenciais, a bondade criada e a alienação. Esse é o conceito de ambiguidade. Para Tillich, a busca por uma vida sem ambiguidade é na realidade o anseio do ser humano pela vida eterna. Por isso, o caráter não ambíguo da vida só pode se dar na eternidade, com o término da tensão conflituosa entre a essência e a existência, o sagrado e o demoníaco (Cf. TILLICH, 2014, p. 563-566). Obviamente, a partir desse ponto se estabelecem as características que determinam, também, as ambiguidades da religião.

O conceito de ambiguidade é fundamentalmente um conceito ontológico, que possibilita a compreensão da importância que a vida humana ocupa no pensamento de Tillich. ${ }^{3}$ Nesse sentido, a ambiguidade tem como objetivo explicar como na vida humana estão presentes as possibilidades do positivo e do negativo, do criativo e do destrutivo, já que a vida está em uma relação dialética constante (MARASCHIN, 1995, p. 90-92). Tillich ressalta que as ambiguidades da vida não são ruins em sua essência, e possibilitam que as qualidades do sagrado e do profano estejam sempre presentes nas estruturas das realidades humanas (TILLICH, 2014, p. 547). A formulação da pergunta ontológica deve considerar então não somente o mistério do ser, como também a indagação do não ser.

Em contraste com todos os outros âmbitos em que as ambiguidades da vida se manifestam, a autotranscendência da vida na religião mostra uma dupla ambiguidade. A primeira delas é expressa na característica universal da vida, a ambiguidade do santo e do profano, do secular e do sagrado. A complexidade torna-se ainda maior quando se percebe que não só a religião demonstra suas ambiguidades por meio dos aspectos "secular e sagrado", mas como esses próprios aspectos são ambíguos em si mesmos. $\mathrm{Na}$ esfera do sagrado, surge a polaridade do divino e do demônico. O problema vai ainda mais além quando se observa também que não só o sagrado é ambíguo, como também o são o divino e o demônico, uma vez que compartilham o poder do sagrado (CRUZ, 2008, p. 132).

\footnotetext{
É importante ressaltar que o conceito de vida abordado neste ponto do artigo não se refere ao conceito de "vida orgânica", mas sim de vida ontológica, universal e que trata das dimensões relacionadas às questões do ser. É a reflexão a partir de um conceito de vida ontológica que problematiza e apresenta a realidade da ambiguidade como a mistura de essência e existência e que se demonstra um elemento vital para a reflexão ontológica no pensamento de Tillich (Cf. CRUZ, 1995, p. 87-92).
} 
Para compreender essa dialética complexa que parece não ter fim, primeiro é preciso entender o lugar que a religião ocupa (ou deve ocupar) na vida humana a partir do pensamento de Tillich. Por muito se considerou no campo da teologia que a religião fosse uma função especial do espírito humano. Mas a religião se mostra como a dimensão do espírito humano que carrega a profundidade presente em todas as outras funções. Essa consciência permitiu que a religião descobrisse a sua função moral, apesar desse relacionamento entre moralidade e religião estar também "carregado" de ambiguidades. Dessa forma, a religião procurou o seu lugar na vida espiritual humana, buscando relacionamentos com a moralidade, a ética, a função cognitiva, a dimensão estética e tantas outras funções do espírito humano, mas sem conseguir se firmar em qualquer deles (TILLICH, 2009, p. 42-44). A respeito desse problema, Tillich afirma que:

[A religião] havia procurado um lugar em todos os possíveis campos da vida espiritual sem encontrá-lo. Voltou-se, então, para algo que acompanha todas as atividades humanas e todas as funções da vida espiritual. É o que chamamos de sentimento. Religião é sentimento: parece que nesse ponto a religião achava o que procurara, coisa que muito agradou os que sempre quiseram libertar a moral e o conhecimento de qualquer interferência religiosa. Mas quando a religião é jogada no mero campo do sentimento, deixa de ser perigosa para os empreendimentos humanos racionais e práticos. Pior do que isso, perde a seriedade, a verdade e seu significado supremo. $\mathrm{Na}$ atmosfera da simples subjetividade sentimental sem objeto definido, sem conteúdo supremo, ela morre. Assim, essa também não é a resposta à busca da religião como aspecto fundamental do espírito humano (TILLICH, 2009, p. 43-44).

Essa afirmação de Tillich, como se percebe, revela que a religião sofreu uma crise sobre o espaço que ocupa no mundo moderno. Por um lado, com o avanço da ciência moderna, a validade da religião foi questionada, contestada e até mesmo ridicularizada pelo pensamento científico crítico. Por outro lado, a religião procurou responder, buscando controlar a cultura ou algumas funções culturais como a ciência, a arte e a política. Tentou sujeitar essas expressões culturais à sua voz heterônoma e, nesse sentido, se viu dentro de uma tensão. Assim, a religião perambulou por todos os campos da vida espiritual humana em busca de sentido e espaço, algumas vezes se travestindo, outras vezes criando tensões e gerando cisões. Mas, como demonstra Tillich, ela permaneceu sem encontrar o seu lugar real e legítimo na dimensão da vida humana. A resposta para essa situação é considerada por 
Tillich quando a religião deixa de se compreender como conjunto de regras, dogmas e ritos, e entende sua verdadeira natureza como preocupação última. Nesta linha de raciocínio, Tillich afirma o seguinte:

Nesta situação, sem lugar próprio, sem ter onde habitar, de repente a religião percebe que não precisa de nada disso. Dá-se conta de que já possui seu lugar próprio em todos os lugares, principalmente nas profundezas das funções da vida espiritual humana. A religião é a dimensão de profundidade em todas elas. É o aspecto dessa profundidade na totalidade do espírito humano. Mas o que significa a metáfora da profundidade? Quer dizer que o aspecto religioso volta-se para os elementos supremos, infinitos e incondicionados da vida espiritual. A religião (...) é "preocupação última", manifesta em todas as funções criativas do espírito bem como na esfera moral na qualidade de seriedade incondicional que essa esfera exige (TILLICH, 2009, p. 44).

Como afirmado, a religião não é apenas uma função especial da vida espiritual humana, mas é a dimensão de profundidade de todas as outras funções. Ela apresenta a qualidade do incondicional, que permite ao espírito humano alcançar o seu caráter na autotranscendência. A religião, como preocupação última, dá sentido a todos os movimentos da alma humana que se formam culturalmente.

Esse caráter de autotranscendência da religião apresenta a primeira ambiguidade da religião em sua própria função. A religião proporciona a autotranscendência, mas, também, a profanização. Esse caráter da profanização da religião tem a intenção de transformá-la em objeto finito entre os demais objetos finitos. O sentido de ser da religião se baseia na manifestação do sagrado, o fundamento divino do ser. Por isso a grandeza e a dignidade da religião se caracterizam como resposta receptiva às experiências revelatórias dessa manifestação do sagrado (TILLICH, 2014, p. 556). Negar essa realidade da religião é o mesmo que transformá-la em algo profano, isto é, reduzi-la a uma função como outra qualquer do espírito humano.

Esse problema torna-se nítido tanto por parte de ataques das ciências críticas à religião institucionalizada como pelas reflexões que nascem dentro da própria religião organizada. Os ataques honestos contra a religião organizada, geralmente, se limitam à ambiguidade da religião no contexto de sua forma institucional, quando se limita a apresentar um conjunto de doutrinas formuladas que devem ser aceitas. Os críticos não conseguem mais reconhecer a validade da religião nessa estrutura. Nesse sentido, mos- 
tra-se o problema dentro da própria expressão da religião, que abandona sua profundidade como preocupação última na vida espiritual humana, e quer desempenhar outros papéis, ocupando o posto de outras funções como a moral e a política. Agindo assim, ao invés de transcender o finito na direção do infinito, a religião institucionalizada de fato se torna uma realidade finita em si mesma, torna-se profana.

Por isso, na opinião de Tillich, os críticos dessa religião tornada profana têm razão em sua crítica e acabam prestando melhor serviço à religião do que às pessoas e grupos que eles atacam. Contudo, é utópico tentar utilizar essas críticas para eliminar as tendências profanas na vida religiosa e conservar apenas o seu puro aspecto autotranscendente. Em todas as formas de religião estão presentes também os efetivos elementos profanizantes. Por isso, essa ambiguidade da religião não é certamente um problema a ser vencido, uma vez que não tira a grandeza da religião como preocupação última. Mas a vida, ao se transcender pela profundidade concedida pela religião, permanece, ao mesmo tempo, dentro de si mesma e nisso se manifesta esse caráter ambíguo (Cf. TILLICH, 2014, p. 555-559). Assim, essa ambiguidade da religião se evidencia tanto no processo de profanização reducionista quanto no centro da autotranscendência religiosa. A forma como isso acontece sugere o conceito mais amplo de religião como experiência do incondicional, tanto no imperativo moral quanto na profundidade da cultura. Além disso, para Tillich, a religião sempre irá se mover entre os perigos extremos da profanização e da demonização e, por isso, em todo ato genuíno da vida religiosa apresenta ambas as características. Por isso, é inclusive possível que a profanização redutiva consiga abolir a religião institucional como função especial da vida humana, mas ela é incapaz de eliminar a religião como qualidade presente em todas as outras funções do espírito - a qualidade da preocupação última.

Assim, também por esse caráter de profundidade, a história das religiões no pensamento de Tillich é também uma luta utópica contra o demônico. Essa luta, porém, é caracterizada pela ambiguidade entre o religioso e o metafísico, onde a religião se vê obrigada a aceitar a contribuição positiva do aspecto demônico nessa história. Isso significa que a religião luta contra o mesmo princípio sem o qual não apareceria. Por isso, como o sagrado, o demônico se mostra é ambíguo. O aspecto demônico da religião é um princípio, ao mesmo tempo, criativo e destrutivo e abrange elementos significativos e também sem significados relevantes. A partir do pressuposto tillichiano de que a vida é ambígua, isto é, nela existe a mistura de elementos 
essenciais e existenciais, e que a existência somente é possível por causa da alienação essencial, pode-se entender que para Tillich o equivalente religioso da ambiguidade é o demônico (Cf. CRUZ, 2008, p. 133-134). Naturalmente, o reconhecimento dessa ambiguidade da religião não significa que Tillich faça uma avaliação positiva do demônico, mas sim que ele tenta ser compatível com a dialética, procurando sempre ressaltar que a presença de um caráter destrutivo é o que torna possível a forma religiosa e também a cultural, embora o destrutivo não seja algo que deva ser desejado ou mesmo almejado.

Assim, a ambiguidade da autotranscendência aparece nessa dialética do divino e do demônico. $\mathrm{O}$ demônico não resiste à autotranscendência como o profano, mas distorce a autotranscendência, identificando um portador particular da santidade com o próprio sagrado. É nesse sentido também que Tillich compreende o conceito de idolatria, uma vez que o que caracteriza o demônico é a reivindicação de infinitude ou grandeza divina por parte do finito. Por isso, a busca da vida sem ambiguidade se dirige, mais radicalmente, contra a ambiguidade do sagrado e do demoníaco no âmbito religioso. A manifestação do caráter demônico da religião se dá na reivindicação de divindade sobre uma base finita. Acontece na elevação de um elemento da finitude à condição de poder e sentido infinito, que só cabem àquele que porta o poder da autotranscendência. Por isso, toda vez que o demônico se manifesta, ele demonstra traços religiosos, seja em aparência moral ou cultural.

Essa discussão sobre a ambiguidade divino-demoníaca da religião gira em torno do problema da doutrina religiosa, principalmente em seu caráter heterônomo. O conflito existente se verifica entre a verdade consagrada do dogma e a verdade que une mudança dinâmica e forma criativa (TILLICH, 2014, p. 563). O caráter heterônomo da religião demonstra sua realidade demoníaca quando exige obediência honesta às estruturas da verdade considerada absoluta.

As ambiguidades da vida se manifestam sob todas as dimensões, em todos os processos e em todos os âmbitos. Por isso, a pergunta pela vida sem ambiguidade está latente em toda parte. O ser humano anseia conscientemente pela realização não ambígua de suas possibilidades essenciais. Para Tillich, a vida sem ambiguidade é simbolicamente a vida eterna, e pode ser descrita como a vida sob a Presença Espiritual, também um símbolo que remete à dimensão do espírito, cujo portador é o próprio ser humano. Por isso, como em todas as dimensões da vida humana, a ambiguidade na religião é também enfrentada pela consciência da finitude. Assim, a religião, como preocupação 
última, confere sentido a todas as outras funções do espírito humano, possibilitando a autotranscendência e a superação da ambiguidade, ainda que esta continue se fazendo presente. Essa é a grande utopia da religião.

\section{Crítica ao exclusivismo cristão}

Embora Tillich não se tivesse proposto formular uma teologia das religiões, há em sua produção teológica demonstrações relevantes dessa preocupação. A primeira foi a elaboração, com Mircea Eliade, de "um tipo de teologia fundamentada na revelação universal de Deus na história das religiões" que, todavia, é "purificada pelo evento do Cristianismo enquanto religião particular". Outra, foi o desejo dele, já no final de sua vida, de interpretar sua Teologia Sistemática a partir da história das religiões (Cf. TILLICH, 1966). Mesmo por ocasião da produção dessa obra, o autor já indicava que, do ponto de vista metodológico, um sistema teológico necessita ser elaborado e refletido sempre em confronto com as questões advindas das críticas do pensamento secular, por um lado, e em diálogo criativo com o pensamento teológico de outras religiões, por outro. Além disso, é necessário considerar a relação entre catolicismo e protestantismo.

É oportuno afirmar mais uma vez que o contexto da produção desse teólogo fazia ressaltar uma preocupação central com a crítica "ateia" da religião, em especial a partir do existencialismo, do freudianismo e do marxismo. No contexto atual, em especial o latino-americano, o pensamento cristão necessita, além de pressupor os referidos questionamentos, debruçar-se nas questões que emergem com a explosão religiosa no mundo inteiro. Trata-se da difícil passagem interpretativa da modernidade para a pós-modernidade.

Tillich destacou, ao mesmo tempo, a importância do caráter normativo da cristologia para a teologia das religiões. Dessa forma, não se pode confundir o caráter particular do cristianismo como uma religião histórica com o caráter particular de Cristo como mediador do absoluto na História (Cf. GEFFRÉ, 1994, p. 268-271).

Para desenvolver essas perspectivas, Tillich reflete sobre o paradoxo do cristianismo ancorado na "Palavra que se fez carne", e em sua situação, igualmente paradoxal, como religião de revelação final, e também recorre à concepção teológica da preocupação última e suprema como o critério de encontro entre religiões. O ponto culminante desses debates é a questão salvífica. Ela é crucial para o diálogo inter-religioso, assim como para uma teologia das religiões. 
Tillich, em "O significado da história das religiões para um teólogo sistemático", conferência realizada dias antes de sua morte, apresenta cinco pressuposições sistemáticas para a abordagem teológica das religiões (TILLICH, 1966, p. 80-94). A primeira é que as experiências de revelação são universalmente humanas. As religiões são firmadas sobre algo que é dado para o ser humano, onde quer que ele viva. A ele é dada uma revelação, um tipo particular de experiência, o qual sempre implica um poder salvífico. Revelação e salvação são inseparáveis, e há poder de revelação e de salvação em todas as religiões.

O segundo aspecto é que a revelação é recebida pelo ser humano nas condições de caráter alienado que possui e na situação humana finita e limitada. A revelação é sempre recebida em uma forma distorcida, especialmente se a religião é usada como "meio para um fim" e não como um fim em si mesma. Em toda a história humana, não há somente experiências revelatórias particulares, mas há um processo revelatório, no qual os limites de adaptação e as deficiências de distorção são sujeitos à crítica, seja mística, profética ou secular. Esse é o terceiro pressuposto.

O quarto é que há um evento central na história das religiões que une os resultados positivos dessa crítica e que nele e sob ele as experiências revelatórias acontecem. Um evento, portanto, que faz possível uma teologia concreta com um significado universal.

O último pressuposto é que a história das religiões, em sua natureza essencial, não existe ao lado da história da cultura. O sagrado não está ao lado do secular, mas ele é a sua profundidade. O sagrado é o chão criativo e ao mesmo tempo um juízo crítico do secular.

Com esses pressupostos, Tillich oferece indicações para uma teologia das religiões, entre as quais três estão relatadas a seguir. A compreensão do autor é que essa teologia reúne uma crítica e uma valorização positiva da revelação universal. Ambas são necessárias. A teologia das religiões, na visão de Tillich, ajuda os teólogos sistemáticos a entenderem o presente momento e a natureza do próprio lugar histórico do fazer teológico, tanto no caráter particular do cristianismo como na reivindicação de universalidade deste (Cf. TILLICH, 1966, p. 81-84).

O caráter paradoxal do cristianismo origina-se no paradoxo "a Palavra se fez carne". Compreende-se o significado da expressão "paradoxo" no fato de um evento transcender todas as expectativas e possibilidades humanas. Essa é a perspectiva de Tillich sobre a encarnação. A reflexão acerca da idolatria necessita dessa argumentação teológica. 
Tillich indicou que o caráter revelatório "em Jesus como o Cristo" como centro da História - confere ao cristianismo um progresso em relação à revelação final. Todavia, essa noção de progresso será relativizada em função da preocupação última já respondida nesse evento revelatório, que rompe o poder demônico na realidade. Nesse sentido, fica excluída a concepção de um progresso horizontal como fim da História e ressaltada a noção de uma interação vertical da Presença Espiritual na História.

A função essencial de Cristo como o Novo Ser é salvar a humanidade de sua alienação e renovar o universo. É em Jesus, confessado como o Cristo, que o Novo Ser, o qual é o princípio da transformação de toda a existência histórica e da renovação da criação, é manifestado. Trata-se de afirmar que "se alguém está em Cristo, é nova criatura; as coisas antigas já passaram; eis que se fizeram novas" (2 Coríntios 5,17).

Ao mesmo tempo, é o Novo Ser em Jesus, como o Cristo, que constitui a norma material da Teologia Sistemática (TILLICH, 2014, p. 62). Nesse sentido, Tillich, mais do que situar-se na perspectiva da justificação pela fé (como fez Lutero), orienta sua teologia na perspectiva da nova criação - o que, mais uma vez, abre perspectivas para o diálogo com a teologia latino-americana, uma vez que essa, desde as suas primeiras produções, enfatiza o surgimento do novo, a transformação social e a tematização, no campo pastoral, da visão bíblica do "novo céu e da nova Terra".

Com isso, o teólogo não estimula a eliminação do paradoxo cristológico em benefício de um maior teocentrismo ecumênico; ao contrário, é precisamente na confissão de Jesus ser o Cristo é que há a chance de assegurar para o cristianismo o diálogo não autoritário. Há uma particularidade (Jesus) conectada a uma universalidade (Cristo) que mantém o cristianismo como religião singular, na medida em que atesta a revelação final. Tal revelação é inseparável do mistério da morte e da ressurreição; e o significado último dela, firmado na doutrina de Cristo como o Novo Ser, é encontrado na Cruz.

A particularidade singular e relativa do cristianismo é possibilitada pela cruz. Ela é a condição da glória. A cruz tem um valor simbólico universal, uma vez que o Cristo ressurreto livra a pessoa de Jesus de um particularismo, o qual faria dele propriedade de um povo particular.

A perspectiva teológica do martírio e do sofrimento humano - ênfase constante na teologia latino-americana - constrói bases comuns de encontro das religiões, pois são experiências que abrangem a universalidade da dimensão humana. Ao mesmo tempo, a cruz e o martírio podem ser elementos 
de discernimento das propostas religiosas. No contexto latino-americano, as experiências relacionadas à Teologia da Prosperidade, por exemplo, tendem a omitirem ou camuflarem ideologicamente a perspectiva da cruz.

O cristianismo é ancorado, portanto, em uma ausência (o túmulo vazio). E é essa consciência do vazio que oferece condições para o relacionamento com o outro. Nesse sentido, o diálogo com outras religiões é uma vocação cristã (Cf. GEFFRÉ, 1994, p. 273-275).

Tillich enfatiza o paradoxo do cristianismo como a religião da revelação final. Para ele, realização histórica alguma constitui a essência do cristianismo; este é essencialmente um protesto contra um conceito histórico de essência. Isso quer dizer que a essência do cristianismo não coincide com qualquer de suas realizações históricas, e que ela pode ser encontrada em outras religiões que não o cristianismo.

As práticas religiosas exclusivistas e o eclesiocentrismo que por vezes configuram o pensamento e as práticas das igrejas são combatidos pela noção de que a Comunidade Espiritual é criada pela Presença Espiritual, e não por mera iniciativa humana, e se revela na humanidade, tanto em grupos seculares como em diferentes religiões, e não apenas nas formas históricas das igrejas.

Nesse sentido, para Tillich, há historicamente uma tensão entre a verdade do cristianismo e a superioridade dele. O paradoxo consiste na declaração de que o cristianismo como religião da revelação final nega o clamor de incondicionalidade por parte de qualquer religião particular, a começar pelo próprio cristianismo. Trata-se de uma preocupação última que possibilita a distinção entre a essência da revelação e a forma concreta e histórica dela.

O paradoxo da perfeita revelação consiste no fato de que ela precisa reconciliar em seu interior os elementos de realização concreta e o protesto perturbador que nega tal realização. $\mathrm{O}$ que dificulta o diálogo inter-religioso é que cada religião quer possuir a revelação final, a revelação do Absoluto. Todavia, a missão da igreja, ao contrário, não é converter as pessoas para a própria igreja e sim para a natureza incondicional da revelação final. $\mathrm{Na}$ superação dessa tensão encontram-se possibilidades de aproximação e de diálogo entre as religiões.

Tillich indica que as experiências revelatórias em todas as religiões são participações fragmentárias na unidade transcendente da vida sem ambiguidades (Cf. GEFFRÉ, 1994, p. 277-280). Isso se encontra, sobretudo, nos conceitos de Comunidade Espiritual latente e manifesta, os quais relativizam a identificação destes com as igrejas. 
As igrejas representam, ao mesmo tempo, a atualização e a distorção da Comunidade Espiritual. Atualização, porque as igrejas se autocompreendem como efetivação do Kairos e possuem a vida ancorada na vida transcendente e sem ambiguidade de Cristo. Distorção, porque como igrejas participam na ambiguidade da religião e da vivência humana em geral. Nesse sentido, o encontro das temáticas eclesiológica e soteriológica representa para o contexto latino-americano um desafio teológico e pastoral de fundamental importância.

Tillich indicou que a base religiosa universal é a experiência do Santo dentro do finito. O Santo, como realidade teológica e espiritual fundamental, surge nas coisas finitas e particulares, tanto nas concretas como nas universais. Ele é a base sacramental de todas as religiões. Pode ser visto e ouvido "aqui e agora", não obstante o seu caráter misterioso. A experiência do Santo, como vivência da preocupação última, é a convergência de todas as religiões e permite um critério comum para o diálogo inter-religioso (Cf. GEFFRÉ, 1994, p. 281-285).

Todavia, a base sacramental do que é Santo e último está sujeita, por sua finitude - como referiu-se Tillich - à demonização. Surge a mística, como movimento crítico, como um "para além de", como uma insatisfação com as expressões concretas do Último, do Santo. Este está além de qualquer corporificação. A concretização da experiência última é aceitável, mas possui caráter e valor secundários. Há uma reserva religiosa ao concreto, que evita o sacramentalismo.

Há um terceiro elemento da experiência religiosa que é o profético. Com ele, a dimensão sacramental é criticada em função das consequências demoníacas, como a negação da justiça em nome da santidade. Trata-se do elemento ético, daquilo "que deve ser", da obrigação religiosa ao concreto, que evita o espiritualismo. No entanto, sem as dimensões sacramental e mística, a experiência religiosa torna-se moralismo e se seculariza.

A relação positiva e negativa desses elementos possibilita, à história das religiões, o caráter dinâmico; a todas as religiões, um telos interior, uma preocupação última. Mesmo com reservas à nomenclatura, Tillich sintetizou essa perspectiva como a "Religião do Espírito Concreto". Esta não pode ser identificada com qualquer religião, nem mesmo o cristianismo, mas está, fragmentariamente, no centro da direção e da orientação de todas as coisas.

O processo de concretização da experiência religiosa pode gerar, ao fim, um secularismo, uma vez que a crítica tende a atenuar ou mesmo eliminar o caráter sacramental e místico. Todavia, esse processo não se sustenta 
por si mesmo, uma vez que não possui um sentido maior e último. Por isso, surge uma nova teonomia, ${ }^{4}$ ainda que fragmentariamente. É nesse processo que vivem as religiões (Cf. TILLICH, 1966, p. 86-90).

\section{A dimensão da salvação}

A vocação ecumênica, ao marcar as reflexões teológicas e pastorais, indica que o caráter de apologia, de sectarismo ou de exclusivismo são ou devem ser evitados. Deus é sempre maior do que qualquer compreensão ou realidade humana. Age livremente, em especial na ação salvífica. Nesse sentido, não é preciso estar excessivamente preocupado em descobrir quem é ou será salvo (para utilizar o imaginário comum dos cristãos); mas quem é e o que representa Jesus Cristo para a comunidade cristã. Esse patrimônio teológico é comum aos pensamentos de Tillich e da teologia latino-americana.

Essas constatações foram feitas para explicitar melhor um ponto de partida: o pecado humano e a superação dele em Jesus, o Cristo, como poder de salvação. Trata-se, sobretudo, da salvação do ser humano em sua "negatividade última", como nos indicou Tillich (TILLICH, 2014, p. 450). É salvar o humano de sua exclusão da unidade universal do Reino de Deus e assim possibilitar-lhe a Vida Eterna.

Isso se refere a uma das questões centrais das reflexões cristológicas e/ou soteriológicas atuais: tratar da salvação a partir do pecado humano. Jaci Maraschin, situa que:

(...) esse ponto de partida tem caracterizado todas as teologias ortodoxas e tradicionais. $\mathrm{Na}$ escolha desse lugar teológico fundamental Tillich está longe de inovar. A teologia da Queda e do Pecado Original tem sido utilizada para acentuar o que se poderia chamar de 'experiência de culpa' e a consequente valorização do ministério do perdão. Tem havido e há, no entanto, movimentos que preferem não partir desse ponto mas da 'bênção original', retirando das descrições da existência o pessimismo que a mitologia da queda e do pecado original ressalta. É o conhecido caso de Matthew Fox com sua teologia mais otimista expressa em obras como Original Blessing - a primer in Creation Spirituality e The Coming of the Cosmic Christ (MARASCHIN, 1995, p. 76).

4 Teonomia é a proposta feita por Tillich para solucionar a problemática da ambiguidade da lei moral. A melhor forma de se entender a teonomia é compreendendo que ela está em consonância com a autonomia e unida à profundidade do incondicional ou, nas palavras de Tillich, ela "significa a razão autônoma unida à sua própria profundidade" (Cf. TILLICH, 2014, p. 98). 
A produção teológica latino-americana e a de Paul Tillich, como se sabe, enfatizaram o aspecto do pecado social. Jean Richard (1994), no artigo "The Socialist Tillich and Liberation Theology", também analisa as aproximações e as questões entre a Teologia da Libertação e a de Tillich no tocante à relação entre salvação e libertação. Conclui, entre outros aspectos, que: a) Ambas as perspectivas teológicas representam uma considerável contribuição para a superação dos dualismos corpo-alma, realidade terrena-realidade celestial e outras formas similares. b) A situação social de opressão e pobreza é, em si mesma, uma situação pecaminosa (e não somente uma consequência do pecado). Nesse sentido, a libertação dessa situação é também, em si mesma, salvação (não somente uma consequência ou resultado da salvação).

No tocante a Tillich, na questão relativa ao pecado, ele ressaltou ainda a concepção de pecado como a contradição própria da existência humana e o poder de Jesus Cristo como salvador dos pecados de toda a humanidade. A suposta pretensão dessas afirmações já indica a densidade do debate. Todavia, como já referido, a reflexão que privilegia a centralidade da pessoa de Jesus Cristo em relação à salvação humana não deve inibir o diálogo teológico inter-religioso, mas na medida em que elucida mais adequadamente a Cristo, como símbolo da sujeição e ao mesmo tempo da superação da existência humana, pode então constituir-se como critério paradigmático de uma teologia mais universalista.

Em plano semelhante, na reflexão latino-americana, estão as indicações de Marcelo Azevedo:

O diálogo supõe que cada um dos parceiros seja ele mesmo e como tal se manifeste e seja acolhido. Seu fruto principal é a percepção da diferença entre ambos e, por conseguinte, a intuição mais aguda das respectivas identidades. Ao conhecer melhor o outro, cada um se conhece melhor a si. O que poderia parecer um fator que aprofunda a discrepância e alarga a distância torna-se caminho privilegiado de uma nova perspectiva (AZEVEDO, 1993, p. 18).

Tillich, em um fragmento do segundo volume de sua Sistemática (TILLICH, 2014, p. 450-464), apresenta aspectos teológicos referentes à afirmação de Jesus, o Cristo, como critério último de todo processo salvífico. A pressuposição de Jesus Cristo como poder de salvação dos pecados está no caráter da revelação divina. Não se trata de um tipo de informação a respeito da realidade divina ou de mera comunicação extraordinária; mas de um impacto, de uma consonância de sentimentos, existencialidades e 
espíritos, de um encontro fundamental ancorado num despojamento divino. Ou, nas palavras de Tillich, "a manifestação extática do Fundamento do Ser em eventos, pessoas e coisas" (TILLICH, 2014, p. 451-452). Assim, compreende-se a revelação.

Essa manifestação privilegia a humanidade. Deus se sujeita a ela; quer ser humano. Ao assumir a existência humana, Ele recupera as questões da vida e da morte: da vida, porque é criador e misericordioso; da morte, porque é humano. Ser humano é participar da alienação à qual a criação foi submetida.

A reflexão e a tensão entre a vida e a morte produzem, pelo menos, duas interpelações. A primeira é que a fé cristã, como indicou José Comblin, não pertence, fundamentalmente, à ordem do conhecimento e da representação política ou eclesiástica, mas sim, da vida, em seu sentido amplo e radical. Para ele:

(...) ser cristão não é revestir-se de um conjunto de conhecimentos ou de estruturas. É viver, libertar-se do que não é vida, para viver plenamente. Jesus se define assim: a vida, o caminho, a porta, o pão, a luz. Ele dá a vida, a saúde, o dinamismo, atira à ação. Não se trata simplesmente da vida biológica, nem tampouco de uma realidade estranha à vida biológica: trata-se desse tônus vital que é parte da responsabilidade de cada um na sua intensidade de vida (COMBLIN, 1980, p. 81).

A segunda interpelação teológica é que toda e qualquer teologia que ocultar as estruturas autodestrutivas da existência humana poderá ocultar Deus. Esse foi o caminho altamente perigoso por onde caminharam as teologias liberais, não obstante a substancial contribuição destas para a comunicação da mensagem cristã ao mundo moderno. O mesmo pode ocorrer com setores da Teologia da Libertação latino-americana, uma vez que a concepção do progresso humano, ainda que de corte não-cientificista, corrobora com propostas exacerbadamente centradas no êxito humano, na tentativa de se privilegiar a humanidade de Deus. No entanto, a humanidade de Deus se manifestou fundamentalmente no fracasso humano, ou seja, na morte de cruz; daí a importância de se refletir sobre o evento da cruz e a salvação da humanidade (TILLICH, 1966, p. 89).

As implicações sociopolíticas e religiosas das práticas proféticas de Jesus, como testemunharam as comunidades cristãs primitivas, evidenciam com determinada lógica histórica que o final invariavelmente seria a morte. $\mathrm{O}$ olhar teológico liberal, seja do século passado ou em seus resquícios atuais, 
colocaria Jesus entre os grandes profetas, como exemplo de conduta ética a ser seguido. Por sua vez, o olhar teológico fundamentalista observaria que esse era de fato o propósito premeditado de Jesus e afirmaria que não há salvação fora dele. Todavia, tais respostas não atendem substancialmente à indagação de sentido da morte de Jesus como ato salvador dos pecados humanos. No primeiro caso, a salvação nem está em questão, ela poderá vir naturalmente ou engendrada a partir de processos intra-históricos. No segundo, está a contradição evidente do deus cruel, sanguinário e até mesmo sadomasoquista.

A formação do sentido da salvação começa na ausência dele na humanidade. A vida humana depende, como indicou Paul Tillich, de "forças curadoras" que impeçam que as estruturas autodestrutivas da existência mergulhem na humanidade a ponto de provocar uma aniquilação completa (TILLICH, 2014, p. 451). A revelação de Deus encontra ressonância nessa busca humana. Daí a compreensão de salvação como cura, pois, ao encarnar-se, Deus reúne aquilo que está alienado e disperso. Trata-se de superar o abismo entre Deus e o ser humano, entre o ser humano consigo mesmo, com o seu próximo e com a natureza.

A consciência religiosa, como preocupação última, afirma sempre a transcendência incondicional ao lado da concretude que torna possível o encontro humano-divino. Nesse sentido, o processo de salvação só é possível com uma mediação. Jesus Cristo, no contexto da fé cristã, "representa Deus diante dos seres humanos e os seres humanos diante de Deus" (TILLICH, 2014, p. 454). É o que teólogos que tratam do tema do pluralismo religioso afirmam. Jacques Dupuis, por exemplo, no debate em torno das religiões, indica que:

$\mathrm{Na}$ realidade, o cristocentrismo da tradição cristã não se opõe ao teocentrismo. Não coloca jamais Jesus no lugar de Deus; afirma somente que Deus colocou-o no centro de seu plano de salvação para a humanidade, não como fim último, mas como caminho, não como a meta de toda a busca humana de Deus, mas como mediador universal da ação salvadora de Deus para com a humanidade. A teologia cristã não se encontra, então, face a um dilema: ser cristocêntrica ou teocêntrica. Ela é teocêntrica sendo cristocêntrica e vice-versa. Isto quer dizer que Jesus Cristo é o sacramento do encontro de Deus com os homens (DUPUIS, 1993, p. 83-84).

Em Jesus Cristo, foi possível o acesso do ser humano a Deus, na medida em que ele reuniu o infinito da transcendência com a finitude humana. Em Jesus Cristo, foi experimentada a vontade reconciliadora de Deus por 
As religiões diante da preocupação última da vida: 373 uma reflexão a partir do pensamento de Paul Tillich

excelência. Esses dois aspectos identificam Cristo como mediador por intermédio de quem Deus age salvificamente em favor da humanidade. Como o Novo Testamento registra: "Tudo provém de Deus, que nos reconciliou consigo mesmo por meio de Cristo e nos deu o ministério da reconciliação, a saber, que Deus estava em Cristo reconciliando consigo o mundo..." (2 Coríntios 5,18,19).

A superação da ambiguidade humana encontra resposta na tensão vivida por Jesus Cristo entre as forças curadoras nele reconhecidas e as estruturas autodestrutivas da existência humana. Por isso o critério da salvação encontra-se em Jesus, o Cristo, uma vez que sua vida não oculta a limitação humana (objetiva) ao revelar a possibilidade da morte a ser assumida (objetivamente) pelos seres humanos e, ao mesmo tempo, possibilita a estes a participação (subjetiva) no poder de Deus ao vivenciar a superação da morte (subjetivamente) com o sentido da salvação.

Essa perspectiva de Tillich o remete à busca de um novo paradigma para a teologia das religiões. Trata-se da superação dos seguintes modelos: o que considera Jesus Cristo e a igreja como caminho necessário para a salvação; o que considera Jesus Cristo como caminho de salvação para todos, ainda que implicitamente; e aquele no qual Jesus é o caminho para os cristãos, enquanto para os outros o caminho é a sua própria tradição.

O caráter salvífico de Cristo, como foi descrito, possibilita formulações e vivências de fé mais espontâneas e ao mesmo tempo profundas e compromissadas social e comunitariamente. Ao mesmo tempo, o caráter dialogal presente em todas as perspectivas teológicas apresentadas impõe-se como conteúdo teológico e como desafio metodológico para a atualidade. A realidade latino-americana, por suposto, requer um aprofundamento dessas questões, em especial pela diversidade e pela afirmação religiosa, nas últimas décadas do século XX, de diferentes agrupamentos, especialmente os que valorizam as raízes africanas e indígenas.

\section{Considerações finais}

Nesta presente reflexão, retomamos o conceito de religião no pensamento de Tillich, observando que o seu papel não deve ser o de ocupar simples caráter normativo ou de substituição dos papéis da moral, da política ou da ética. Em Tillich, a religião tem o sentido de preocupação última. Isso significa que ela desapossa todas as outras preocupações de uma significação última - isto é, principal na vida humana - e as transforma em preocupações 
secundárias. Tillich é um pensador preocupado com a vida humana. Para ele, a religião não deve ser compreendida como função especial do espírito humano, mas precisa retomar esse princípio da preocupação última, como a função do espírito humano que dá sentido e profundidade a todas as outras funções criativas do espírito humano. A preocupação última é incondicional e independente das engrenagens ideológicas e, por esse motivo, é também total, incondicional e infinita. Por sua vez, as formas religiosas e as ambiguidades da religião sempre estarão presentes, como mostra a História, especialmente a realidade atual.

Dessa forma, como visto no texto, a partir da consideração do conceito tillichiano de preocupação última, os horizontes se abrem para a reflexão no campo da teologia das religiões. O diálogo entre as religiões torna-se em um processo dificultado quando são adotadas posturas de caráter exclusivista, o que objetivamente criticamos no texto. Esse problema pode ser identificado também devido às ambiguidades presentes na religião e no seu caráter demônico e destrutivo. Contudo, a consciência religiosa como preocupação última reafirma sempre a transcendência incondicional ao lado da concretude que torna possível o encontro entre o divino e o humano. Por isso, diante das realidades teológicas, doutrinárias e vivenciais das religiões, procuramos estabelecer um caminho que aponte para a superação, ainda que provisória, dessas ambiguidades e desses conflitos.

O pensamento de Tillich aponta para a compreensão de que a superação das ambiguidades humanas, isto é, a busca pela vida eterna, dá-se no encontro entre o ser e a figura do Novo Ser, identificado no cristianismo com a figura do Cristo. Justamente por isso, a fé cristã que identifica na figura do Cristo o critério para a salvação humana da alienação e das realidades ambíguas, precisa compreender sua vocação para o diálogo frente ao quadro do pluralismo religioso. Essa perspectiva nos aponta para a busca de novos paradigmas para a teologia das religiões e a reflexão a partir do pensamento tillichiano é um saudável instrumento. As fés precisam ser reinterpretadas a partir do critério daquilo que nos toca incondicionalmente, para abraçar o caráter transcendental que conduz o ser humano à profundidade do seu próprio ser. Assim, tais reflexões apontam para um caminho de caráter transformador, reformador e utópico. 
As religiões diante da preocupação última da vida: 375

uma reflexão a partir do pensamento de Paul Tillich

\section{Referências}

AZEVEDo, M. Prólogo. In: TEIXEIRA, F. L. C. (Org.). Diálogo de Pássaros. São Paulo, SP: Paulinas, 1993.

COMBLIN, J. O debate atual sobre o universalismo cristão. Concilium, n. 155, 74-83, 1980.

CRUZ, E. R. A Dupla Face: Paul Tillich e a ciência moderna. São Paulo, SP: Loyola, 2008.

DUPUIS, J. O debate cristológico no contexto do pluralismo religioso. In: TEIXEIRA, F. L.

C. (Org.). Diálogo de Pássaros. São Paulo, SP: Paulinas, 1993, p. 75-88.

GEFFRÉ, C. Paul Tillich and the future of interreligious ecumenism. In: BULMAN, R. F.; PARRELA, F. J. (Orgs.). Paul Tillich: a new catholic assessment. Collegeville: Minnesota-USA, A Michael Glazier Book, 1994, p. 268-288.

MARASCHIN, J. A linguagem ontológico-existencialista de Tillich. Estudos de Religião Paul Tillich: Trinta anos depois, Ano X, n. 10, p. 11-36, 1995.

RIBEIRO, C. O. Pode a fé tornar-se idolatria? A atualidade para a América Latina da relação entre reino de Deus e história em Paul Tillich. Rio de Janeiro, RJ: Instituto Mysterium; Mauad X, 2010.

RICHARD, J. The Socialist Tillich and Liberation Theology. In: BULMAN. R. F. \& PARRELA, F. J. (Orgs.). Paul Tillich: a new catholic assessment. Collegeville: Minnesota-USA, A Michael Glazier Book, 1994, p. 148-173.

SANTOS, J. M. G. A Teologia da Cultura. In: MUELLER, E. R.; BEIMS, R. W. Fronteiras e Interfaces: O pensamento de Paul Tillich em perspectiva interdisciplinar. São Leopoldo, RS: Sinodal, 2005.

TILLICH, P. A Coragem de Ser. Trad.: E. Malheiros, 6. ed. Rio de Janeiro, RJ: Paz e Terra, 2001.

TILLICH, P. Dinâmica da fé. Trad.: W. Schlupp, 3. ed. São Leopoldo, RS: Sinodal, 1985.

TILLICH, P. Teologia da cultura. Trad.: J. Maraschin. São Paulo, SP: Fonte Editorial, 2009.

TILLICH, P. Teologia Sistemática, 7. ed. São Leopoldo, RS: EST \& Sinodal, 2014.

TILLICH, P. The Future of Religions. New York-USA: Harper \& Row, 1966.

TILLICH, P. What is Religion. Translated by James Luther Adams. New York, Evanston, San Francisco. London: Harper \& Row, 1973.

Submetido em: 07-09-2016

Aceito em: 13-11-2017 